\title{
THE RECOGNITION OF THE TAMAZIGHT \\ LANGUAGES IN THE ALGERIAN LAW
}

DOI: 10.24193/SUBBiur.64(2019).3.2 Published Online: 2019-09-25

Amar Laidani*

\begin{abstract}
On March $6^{\text {th }}$, 2016, the Tamazight (Berber) languages were recognized by Article 4 of the Algerian Constitution as "official languages". This constitutional review event marked a step forward in the recognition of Tamazight languages in the Algerian legal system. The constitutional recognition of the Tamazight language began in 2002, when the Algerian legislator introduced Article 3 -bis in the Algerian Constitution, recognizing Tamazight as a "national language".

The constitutional review of 2016 was nevertheless welcome with coldness, even with some suspicion from the Kabyle public opinion.

We will attempt through our presentation to clarify the historical origins of the conflictual relationship that Algerian law has maintained with the question of Berber languages, which in the case of Algeria is mostly a Kabyle question.
\end{abstract}

Keywords: Colonial law, Kabyle's customary Law, Linguistic right, Algerian Constitution, National language, Official language.

* Amar Laidani, PhD candidate in «Histoire du droit» at Montpellier University in cosubervision with Laval University; e-mail : amar.laidani.1@ulaval. 


\section{LA RECONNAISSANCE DES LANGUES TAMAZIGH AU SEIN DU DROIT ALGÉRIEN}

Résumé : Le 6 mars 2016, les langues tamazight (berbère) ont été reconnues par l'article 4 de la Constitution algérienne comme « Langues officielles ». Cette révision a marqué un pas en avant dans la reconnaissance des langues tamazight dans le système juridique algérien. La reconnaissance constitutionnelle de la langue tamazight a commencé en 2002, lorsque le législateur algérien a introduit l'article 3-bis dans la Constitution algérienne, reconnaissant le tamazight comme une « langue nationale ». La réforme de 2016 a été tout de même accueillie avec une certaine tiédeur, voire même avec une certaine suspicion de la part de l'opinion publique kabyle. Nous essayerons à travers notre présentation d'éclaircir les origines historiques du rapport conflictuel que le droit algérien a entretenu avec la question des langues berbères, qui dans le cas de l'Algérie, est avant tout une question kabyle.

Mots-clés : Droit colonial, Droit coutumier kabyle, Droits linguistiques, Constitution algérienne, Langue nationale, Langue officielle.

\section{Introduction.}

On March 6 $6^{\text {th }}, 2016$ the Tamazight languages were recognized as "official languages" by the new article 4 of the Algerian Constitution. This event marked a step forward in the recognition of Tamazight languages into the Algerian legal system.

The constitutional recognition of the Tamazight language began in 2002, when the Algerian legislator introduced the article 3-bis in the Algerian Constitution, recognizing Tamazight as a "national language". The 2016 review of the Algerian Constitution grants to Tamazight the double status of "national" and official" language. The Algerian constitutional reform of 2016 comes close to the Moroccan one of 2011 which recognized in 
article 05 of the Moroccan constitution "Tamazight languages" as national and official languages ${ }^{1}$.

So, now in Algeria, theoretically, Tamazight languages in all their varieties have the same legal status as the Arab language. However, the reality is far from the theory. A legal reform cannot repair the fact that in Algeria the Tamazight languages remained ignored for a long time by the legal system. Furthermore, the Constitutional Resolution of April 10 $0^{\text {th }}, 2002$, did not bring the expected progress. Up to now, there are no Tamazight language interpreters in the Courts located in Berber-speaking areas. In addition, the Code of Civil and Administrative Procedure promulgated in 2008, thus after the constitutional revision of 2002, does not provide for any concession to minority languages such as Tamazight. Indeed, article 8 of the aforementioned Code provides that classical Arabic should be the only language of the petitions and pleadings of lawyers, and more generally the only language admitted during the process, and finally the article 212 (4) of the Algerian constitution proclaims that any constitutional review can undermine to the legal status of Arabic as nation and official language.

The current Algerian legislation does not allow the application of the new article 4 of the Algerian Constitution, and so, Algeria is far from being a bilingual legal system.

The question of recognition of the Tamazight language in Algeria is mostly a Kabyle question. Kabylia is undeniably the part of Algeria where the Berber question has been felt most strongly. As Roberts explained:

\footnotetext{
${ }^{1}$ The Tamazigh speakers represent $27 \%$ of the Algerian population and $40 \%$ of the Moroccan population. In: J. LECLERC, Algeria, Location and demo linguistics, internet address: $\mathrm{http}$ : / /www.axl.cefan.ulaval.ca/afrique/algerie-1demo.htm.
} 
"There is no general Berber question in Algeria, still less in the Maghreb as a whole. The Berbers may be regarded as a linguistic category or as an ethnic group, but neither label necessarily connotes 'community' and there is, in fact, no community of interest uniting the Berbers as such”2.

The difficult relationship the Algerian Legal system has maintained with the Kabyle's linguistic right sinks its causes in the history, especially in the colonial and the recent history of Algerian legal system.

First of all, I will expose the colonial origin of the Berber question in Algeria and the reasons why in the Algerian case, the Berber question is, above all, a Kabyle question. I will start explaining the special status that the French colonial legislator granted to Kabyle's customary law and to Kabyle's language during the French colonial era of Algerian history. I will conclude with the root of the Berbers question during the Berber crisis of 1948. In the second part of my work, I will deal with the subject of the Kabyle's language and the Algerian legal system. I will expose how during the first years of Algerian independence; the Algerian legal system denied and ignored the Kabyle's and Berber language in the name of Arabisation of Algeria. Finally, I will expose how the Algerian legal system recognized the linguistic right to the Berbers minorities.

${ }^{2}$ H. ROBERTS, 'Towards an understanding of the Kabyle question in contemporary Algeria', in The Maghreb Review, Vol. n. 5 No. 6, 1980, p. 117. 
2 Kabyle's language and customary law during the French colonial period:

\subsection{Customary Kabyle Law and the French Colonial Administration:}

The Kabylia, a mountainous territory, inhabited by Tamazight (berber) spoken peoples known as Kabyle, was the last part of northern Algeria to be colonized by the French army after a violent military campaign during years $1854-1857$.

Since the XVI century, the Kabyle's tribes developed a selfgovernment political system based on a complicated tribal governance system known as Arch ${ }^{3}$. Before the French conquest, the Kabyle entertained commercial relations with the Algiers Regency territories. So, the Kabyle used the Algerian Arab dialect as a second language. The literary Arab was the language of the erudite, as the local Muslim clergy4.

The french colonization brought profound linguistic changes in Kabylia; the French language became the second language of the Kabyle. This phenomenon was due to the governance that the French imposed in Kabylia during the colonization5.

The French conquest of Kabylia (1857) was accomplished twentyseven years after the capitulation of the Regency of Algiers ${ }^{6}$. At first, this

3 H. RoberTs, 'Berber Government. The Kabyle Polity in Pre-colonial Algeria', London. I. B Tauris, 2014, pp. 165-282.

4 In the beginning of the XIX century Cheikh El Mouhoub has translated in Kabyle the Arabic treaties of el-Àqida es-Senoussia. El Mouhoub used the Arabic alphabet.

5 Ibid.

${ }^{6}$ E. CARREY, 'Récit de Kabylie-Campagne de 1857', Alger. Edition, Grand Alger-livres, 18582007 ; Ch. A. JuLIEN, ' Histoire de l'Algérie contomporaine-1/Conquête et colonisation', Paris, Presse universitaire de France, 1979. 
territory was ruled by the French officers. Kabyle villages were ruled through an indirect administration based on the maintenance of the Kabyle's traditional political institutions as the village's assemblies called djemaas ${ }^{7}$. During the centuries, this institution played a central role in the Kabyle's selfgovernment. The djemaas resolve the disputes between the village's inhabitants and edict the customary law rules. In the customary Kabyle tradition, the assemblies promulgated, in each village customary village's statutes called qanuns ${ }^{8}$. These qanuns were written in literary Arabic.

The traditional political system of Kabyle tribes has attracted the attention of the French militaries. In a first time, before the accomplishment of the conquest of Kabylia, the Kabyle's customs were used as an argument by the armies who advocated the necessity of the conquest of Kabyle's tribal zone. French officers presented the conquest of Kabylia as a necessary step for the accomplishment of the conquest of entire Algeria9. The military's reports published during the years of the conquest (1854-1857) conveyed the idea that independence of Kabylia should represent a danger for the French colonial presence in Algeria while, in the same writings, they claimed that the submission of this territory could give great advantage for the French presence in Algeria. The French propaganda presented the Kabyle populations were by as potential allies of France. The same propaganda described Kabyle's traditional political system as the proofs of the high level

7 CH. R. AGERON, 'La politique kabyle sous le Second Empire', in Revue française d'histoire d'outre-mer, 53 (90-191) 1966, p. 68.

${ }^{8}$ M. GAHLOUZ, 'Les qanouns kabyles-Anthropologie juridique du groupement social villageois de Kabylie', Edition. L'Harmattan, Paris, 2011 ; A. MAHÉ, 'Laïcisme et sacralité dans les Qānūns kabyles, Annales islamologiques', n. 27, 1993, pp. 137-156.

9 P. M. E. LoRcıN, 'Kabyles, arabes, français : identités coloniales', Limoges, Pulim, Presses universitaires de Limoges, 2005, p. 13. 
of democracy and secularism of the Kabyle society. The Kabyle's secular customs were opposed to the Arabic theoretical "sharia" one. This phenomenon was known as the « Kabyle myth».

In 1847 and 1853, two books were published on the history of Kabylia, as well as on Kabyle customs. Soldiers drafted the first: Colonel Daumas and Captain Fabar, a historical study entitled "La Grande Kabylie proprement dite", Colonel Daumas wrote the second and entitled it as "Moeurs et coutumes de l'Algérie"10. In this last work, appeared for the first time in the colonial literature the kabyle qanuns. The latter were customary normative corpora that governed the legal and political life of Kabyle villages.

After the conquest of Kabylia, the interest in Kabyle customs grew increasingly. The Kabyle traditional village's statutes (“qanuns”) have been translated from Arabic to the French language. The most important result of this interest was the codification of the Kabyle's tribal customs in a unique treaty entitled «The Kabylia and the kabyle customs ${ }^{11}$ ». This work was written by a military, Hanoteau, and a judge, Letourneux, after an intensive study of the Kabyle's statutes and an investigation on the field in the Kabyle villages. In 1880 , the Kabyle customs became a subject of instruction in the Faculty of Law of Algiers.

The officers who ruled Kabylia after the conquest applied to the Kabyle's population a regime of legal particularism. The Kabyle were ruled by their customs and their traditional institutions as the djemaas. The officers avoided the presence of Muslim judges in Kabylia.

\footnotetext{
10 E. Daumas, 'Mœurs et coutumes de l'Algérie', Paris, Hachette, 1853.

${ }^{11}$ A. Hanoteau, A. Letourneux, 'La Kabylie et les coutumes Kabyles', Imprimerie impérial, trois volumes, Paris, 1873 .
} 
After the fall of the military regime and the rise of the civil government, in 1871 , Kabylia was reconducted to the authority of the latter. This event coincided with the fall of the regime of Napoleon III and the revolt led by Kabyle Chief El Mokrani and the Sufi Sheikh Haddad.

The main consequence was the fact that the faculty of application of the Kabyle customs was given to French judges ("juges de paix"). After the promulgation of the law of the 29 august 1874, the Kabyle customs were recognized as an official source of law in the legal matters of property and in personal statutes (marriage, divorce, inheritance) ${ }^{12}$. So, unlike the remaining part of Algeria, in the legal matters of property and personal statute, the Kabyle population was subtracted from the rule of the Muslim law and reduced to a particularistic legal customary regime. The primary source of references used by the French judges was « La Kabylie et les coutumes kabyles » or Kabylia and the Kabyle's customary laws. This book was considered by the French judges' nothing more than an unofficial codification of Kabyle's customs made by a magistrate and a soldier, naturally French. This book is a first example in the history of French colonial customary indigenous law, for use by indigenous courts. This writing drew its sources largely from the precepts contained in the kabyle qanuns as well as from an on-the-field work and collaboration with Kabyle notables such as Si Moula n'Ait-Ameur ${ }^{13}$.

During the entire period of French colonization, Kabyle's populations were submitted to a special legal statute. The indigenous populations of Algeria were divided into two categories: the Muslim ruled by Muslim law

12 R. Estoublon, A. LeFebure, 'Code de l'Algérie annoté-1830-1895', Jourdan, Alger, 1896, p. 438.

13 H.-A. MANSOURI, 'La Kabylie dans les écrits français du XIX siècle', Alger Enag Edition, 2011, p. 31. 
and the Kabyle ruled but the customary law, although the Kabyle were and are mostly Muslim. The application of Kabyle customary legal status was based on the rationae personae criterion. Thus, the decree of August $20^{\text {th }}$, 1874 resulted in the ethnicization of the Kabyle's customs. For example, the decree of May $31^{\text {st }}, 1931$, through which the French legislator recognized the inheritance rights for Kabyle women, was applied only to Kabyle women.

That said, the Kabyle's customs were the only customary law which has been officially recognized by the French colonial legislator. At the same time, the Kabyle language was the Berber linguistic variant which attracted most considerable attention of the French academicians. We will analyze the reasons for this phenomenon in the following.

\subsection{B - The study of Kabyle language and customs during colonization}

Throughout the French colonization period, the interest showed by the French military ethnologists about the customs proceeded in parallel with the interest for the Kabyle language.

During the first years after the French conquest of Algeria, the colonial authority showed an early interest in the Kabyle language. Indeed, even before the end of the military conquest of Kabylia, appeared in 1844 an abbreviated French grammar and dictionary of the Berber language written by Venture du Paradis, which was reviewed by Amedee Jaubert ${ }^{14}$.

\footnotetext{
14 V. de PARADIS, 'Grammaire et Dictionnaire abrégés de la langue berbère', revus par A. Jaubert, Société de géographie, Paris, Imprimerie Royale, 1844. A. BounFOUR, J. LANFRY et S. CHAKER, 'Dictionnaire berbère ' in Encyclopédie berbère, 15| Daphnitae-Djado [online], accessed in october 5 2017, URL: http://encyclopedieberbere.revues.org/2255.
} 
The General Letourneux, who was co-author, with the magistrate Hanoteau, of the famous and fundamental work on Kabyle customs, entitled "La Kabylie et les coutumes kabyles" cited above, wrote in 1858 a Kabyle Grammar Essay ${ }^{15}$ and in 1867 a Kabyle poetry miscellany entitled Poésies Populaires de la Kabylie du Jurjura in $1867^{16}$.

During the same period, some treaties on Kabyle language were written by educated Algerian like Ben-Sedira and Boulifa. In the same way as what happened for French authors, the interest in custom were accompanied by that for the Kabyle language. In 1887 Ben-Sedira wrote a Kabyle Language Practice Course ${ }^{17}$. This book contained nine qanuns transcribed in the Kabyle language ${ }^{18}$. During the same period, another native Kabyle language teacher, Amar Boulifa, was interested too by the question of Kabyle customs. Like Ben Sedira, Boulifa was a Kabyle language teacher who wrote a treaty about the Kabyle poetry entitled "Recueil de poésie kabyle"19 in which he dedicated a chapter to the Kabyle customary law.

\footnotetext{
15 A. HANOTEAU, 'Essai de grammaire kabyle, renfermant les principes de ce langage berbère parlé par les populations du versant nord du Jurjura et spécialement par les Igaouaouen ou Zouaoua, avec des textes et traductions, suivi de notes et d'une notice sur quelques inscriptions en caractères dits tifinar' et en langue tamacher't,', Alger, Bastide, 1858.

16 A. Hanoteau, 'Poésies Populaires de la Kabylie du Jurjura', Paris, Imprimerie impériale, 1867.

17 B. BEN SEDIRA, 'Cours de langue kabyle-grammaire et versions', Alger, Librairie Adolphe Jourdan, 1887.

18 B. BEN SEDIRA, op. cit.pp. 295-345. Y. Adli 'Les efforts de Préservation de la pensée kabyle, Tizi-Ouzou', Vol. I, Ed. L’Odyssée, 2010, p. 183.

${ }^{19}$ S. A. BouliFA, 'Recueil de poésie kabyle', (1990),AWAL, Alger.
} 
From the year 1880, the Kabyle customary law was taught at the Faculty of Law of Algiers ${ }^{20}$. At the same time, the Kabyle language was taught and studied in the University of Humanities of Algiers. The teaching of the Kabyle's language was held by the then Chairman of the University of Algiers, Renée Basset.

During the thirties of the $20^{\text {th }}$ century, René Maunier, professor of Law at the University of Algiers and representative of the legal current said folklorist, weaved in his work a parallelism between the Kabyle customs and the Kabyle language. These two elements were opposed to both the Arabic language and Muslim Law. These ideas were expressed in the following terms:

"Kabyle opposes Arabic as a dialect to one language. (...) in the same way that the Kabyles' law is a popular right and a customary law, and thereby it is opposed to the written law of the Muslims. (...) $)^{21 "}$

The doctrine of Law school of Algiers can be summed up around three key ideas: (a) in Kabylia, Kabyle customs prevail over Islamic law, (b) there is a close link between the Kabyle language and Kabyle customs, as well as there is still a link between Arabic and Muslim law, (c) Kabyle customs are closer to French law. This vision ethnicized the Kabyles customary law and opposes it to religious Muslim law, just as custom opposes the law.

The French colonial regime applied in Kabylia a special linguistic policy. On the one hand, there was a widespread schooling of the Kabyle population in the French language. This teaching was given by secular and

${ }^{20}$ C. BonTEMs, 'La coutume kabyle et l'implantation des systèmes étrangers', La réception des systèmes juridiques: implantation et destin, (dir. M. Doucet, J. Vanderlinden), Bruyland, Bruxelles, 1994, p. 89.

${ }^{21}$ R. MAUniER, 'La Nation et l'Etat en Algérie, La nationalité dans la science sociale et dans le droit contemporain', Paris, Editions Librairie. du Recueil Sirey, 1993, p. 198. 
catholic schools. From each side, the French authority applied in the Courts (Juges de Paix) placed in Kabylia a special linguistic regime. Differently from what happened in the other parts of Algeria, the two languages used in the courts were not French and Arabic, but French and the Kabyle variety of Tamazight. The Muslim judge who operated in the few Muslim courts which were present in the oriental part of Kabylia had to take a certificate of Kabyle's language. The article 2 of the decree of the December $9^{\text {th }}, 1910$ provides that the candidate for the function of qadi (Muslim judge) must have a certificate of Kabyle languages or proof of their skills in this language by passing an exam ${ }^{22}$. The candidates were examined by Kabyle teachers of the University of Humanities of Algiers and by professional Kabyle legal translators. The examination was made in front of the President of the Court of Appeal and the General Attorney of the same court ${ }^{23}$. The exams were oral. It was asked to the candidate to translate in Kabyle an official act written in Arabic. The same Kabyle linguistic skills were asked to the teachers and to labour inspector who operated in Kabylia by the Decree application in Algeria of the Labour and Social Insurance Code of the January $15^{\text {th }}, 1921^{24}$.

\subsection{C- The Berber question (1949)}

The French policy of Kabyle assimilation did not work. This fact is proved by the massive participation of the Kabyle in the Algerian National Movement during the Algerian independence war (1954-1961).

\footnotetext{
22 Revue Algérienne Tunisienne et Marocaine de Législation et de jurisprudence, Alger, Volume, XXXII, 1916, p. 58.

23 Ibid.

24 Revue Tunisienne et Marocaine de Législation et de jurisprudence, Alger XXXVIII-XXXIX, 1917, p. 177.
} 
However, a Kabyle question emerged during the previous period of the Algerian War. The so-called "Crise berbèriste" ${ }^{25}$. This question arose during the year 1949, it had almost caused during a short time a fracture inside the Algerian National Movement (MNA) guided by Messali-Haj. The dispute arose around the project of the future Algerian state. During these years, the Kabyle members of the MNA were opposed to the pan-Arabic and Islamist wing of the MessaliHaj's political movement ${ }^{26}$. The Kabyle militants in the movement, such as Abdennour Ali-Yahia the future lawyer of the Algerian League of Human Rights, advocated the importance of the valorization of the pre-Islamic past of Algeria. These militants were strongly influenced by Marxism. This was due to the fact that the Berberists were composed for the most of them by Kabyle emigrants who had joined France since the 1910s. Most of them were militant in the French Communist Party and French leftist Union. So, the political orientation of this current was secular. They advocated the idea of an independent Algeria which was both independent from the French political influence and also from the Middle East cultural influence. Ali-Yahia coined the slogan "l'Algérie algérienne" or an Algerian Algeria. The formula resumes the project of a plural Algeria in which all ethnic groups would have found their place without being there a linguistic or ethnic predominance, so a rule of law that guarantees cultural and linguistic rights to Berber. The latter claimed that the idea of "Arab Algeria" conveyed by the manifesto of the "Liberation Committee of the Arab Maghreb" dated January $5^{\text {th }}, 1948$. The members of the

25 A. OUERDANE, 'La question berbère dans le mouvement national algérien 1926-1980', Québéc Septentrional, 1990, A. OUERDANE, 'La crise berbèriste de 1949, un conflit à plusieurs faces', in Revue des mondes musulmans et de la Méditerranée, 1987, pp. 35-47 ; A. GuENON, 'Chronologie du mouvement berbère, 1945-1990. Un combat et ses hommes', Alger, La casbah, 1990; M. FoIs, 'La minoranza inesistente', Roma, Carocci editore, 2013 p. 47.

${ }^{26}$ M. Fois, op. cit. p. 56. 
Berberist group were critical concerning the manifest itself. It followed that the Berberists suffered a strong repression from the French authorities. The French security services arrested then all the head members of the Berberists present in Kabylia as Amar Ould-Hamouda, Said Oubouzar, Omar Oussedik and Omar Boudaoud. Ouerdane's words are rather exhaustive:

"Victim of the colonial repression as a radical wing of the nationalist movement, fought in the name of Islam by the leadership of the party, the Ulema, the Committee for the liberation of the Arab Maghreb and the Arab League, isolated at the international level, deprived from financial means, the "Berber-materialists" in the end of year 1949 were dispersed 27 ".

As Roberts explains:

“(...) Berberists were quickly purged from the MTLD organization in Kabylia, wich passed under the control of elements then loyal to Messali, chiefs among them Belkacem Krim and Abane Ramdane"28.

Theses chiefs were Kabyle, so the Berber controversy has been suspended during the Algerian Liberation war, despite the fact that the Governor of Algeria, J. Soustelle, tried to revive it ${ }^{29}$. The latter had placed the entire territory of Great-Kabylia under the military rule. Thus, through the decree of September $26^{\text {th }}, 1955$ he established in Kabylia the Specialized Administrative Section, better known as SAS. This section was attached to the Algerian Affairs Department (AA). Soustelle supported the birth in 1959 of the MBA, the African Berber Movement, a pro-colonial and fiercely anti-Arab

27 A. OUERDANE, 'La crise berbèriste de 1949, un conflit à plusieurs faces', Ibid., p. 43.

${ }^{28}$ H. RoBERTs, 'The Economics of Berberism: the Material Basis of the Kabyle Question in Contemporary Algeria, in Government and opposition', Volume 18, number 2, 1983, p. 228.

29 J. Soustelle, 'Troubles, Etat d'urgence. Situation en Kabylie, Cabinet du Gouverneur Général de l'Algérie J. Soustelle', in ANOM, ALG GGA IICAB/38. (Colonial Archives-Aix en Provence) See M. FoIs, op. cit. p. 102. 
Berber movement. This operation had no success. As Camille-Lacoste-Dujardin explains, the then governor J. Soustelle and the ethnologist J. Servier set up a political operation aimed at:

"To use the old and new antagonisms on several local scales between" tribes ", regional between "Kabyle "and" Arab " according to the " Berberism "evoked by the general governor, finally bet on the Kabyle judged pro-French against the "leaders Activists", on the MNA of Messali Hadj against the young FLN30.".

During the first year of Algerian independence, a Kabyle revolt arose against the government of Ahmed Ben Bella in October 1963. However, the leader of this revolt, Hocine Ait Ahmed, avoided the berberist label ${ }^{31}$.

\section{II - THE KABYLE QUESTION IN THE ALGERIAN LEGAL SYSTEM. FROM THE ARABISATION OF THE ALGERIAN LAW TO THE RECOGNITION OF THE TAMAZIGH LANGUAGES}

\subsection{A -The Arabisation of the Algerian legal system (1962-1991).}

The new-born Algerian State has inherited from France colonial past a monolingual legal system and a centralized state. Just as what happened in the other Maghreb countries, the Arabic language has been conceived, by the young Algerian government, as the only language which was able to

\footnotetext{
30 C. Lacoste-Dujardin, ' Opération oiseau bleu, 1956, géostratégie et ethno politique en montagne kabyle', In Revue de l'occident musulman et de la Méditerranée, n. 41-42, 1986, p. 188.

${ }^{31}$ H. Roberts, The Economics of Berberism: the Material Basis of the Kabyle Question in Contemporary Algeria, in op. cit., p. 228.
} 
strengthen the unity of the new-born state and the national sovereignty. So, in one word, Arabic should replace the place occupied, until then, by the French language. As Grandguillaume explains:

"Arabisation is essentially based on two elements: Islam and the nation. The Arabic language operates as a unifying agent at both levels; it intervenes as such from the origins of Islam, it intervenes again in the current phase of structuring the national ideology ${ }^{32}$ ".

In an ancient French colony like Algeria, the political independence from France was to lead also to a linguistic break with the French language, but this break never happened. The only languages which were marginalized were the Kabyle and the other Berber languages. As we saw above, Kabyle's language was the only variant of the Algerian Amazigh language, which has been recognized during the French colonial period ${ }^{33}$. The same happened to the Kabyle's customary law. During the first years after the Algerian independence, every aspect related to Kabyle and, generally, Berber identity

32 G. GRandgullLaume, Arabisation et politique linguistique au Maghreb, (1983), Edition G.P. Maisonneuve et Larose, Paris (V), p. 37.

33 The question of legal protection of Amazigh language reappeared again as a post-colonial question in French law during the discussion about the adoption of the European Charter for Regional Languages of the years 1998-1999. The professor of Public Law, Guy CARCASsonne, wrote a report concerning the legal compatibility between the European Charter abovementioned and the French Constitution. CARCASSONNE had launched the idea - very appreciated by the academic environment of the Berber studies present in France - of considering the Berber language (as well as Yiddish and Romani) as a French minority language for the reason that this language was the mother language of several French citizens having Algerian and Moroccan origin. In the point 176 of his report CARCASSONNE defined the Berber language as.:“(...) the language inherited by hundreds of thousands of us” (French citizens), "which is nowhere officialized" (his report was written in 1999) "not even (.....) in Kabylia the geographical region of Algeria where it is the most spoken language which moreover belonged a long time to a French department”. See G. CARCASSONNE, 'Etude sur la compatibilité entre la Charte européenne des langues régionales ou minoritaires et la Constitution : rapport au Premier ministre', p. 120. 
was perceived by the FLN (National Liberation Front party) government as an element of division of the new-born state. In one word the Berber question was seen a colonial legacy.

During the first year of independent Algeria (1962), the Algerian legislator began an operation that Filali baptized with the French word of "Algerianisation" of the Algerian new-born legal system ${ }^{34}$. This operation was firstly directed to weaken the French legal heritage in Algeria. The French legacy was still strong during the first decade after the decolonization, this was due to the fact that the first law adopted by the Algerian legislator was the law of December $31^{\text {st }}, 1962$, which maintained in force the French legislation. Were excluded only the colonial laws which were considered racist, colonialist and dangerous for to public order35.

The Law of 1962 was repealed in 1974. So, the 1962-1974 period was a transitional period during which the Algerian legislator and the Algerian Courts showed clearly their will of breaking with the colonial legal legacy. On March $27^{\text {th }}$, 1963 was promulgated the law n. 63 which reformed the matter of the Algerian nationality statutes. The main goal of this law was to unify the legal statutes and to put an end to the statutes' pluralism of the colonial era. Starting from that moment, only one category of citizens should exist, the Algerian one ${ }^{36}$.

From the end of the year 1968 until 1975, the Algerian Supreme Court declared an offensive to the French decree of May $19^{\text {th }}, 1931$. This decree, as

\footnotetext{
34 A. FILALI, 'Bilinguisme et bijuridisme, l'exemple du droit algérien, in Le Bilinguisme juridique dans les pays du Maghreb-Acte du colloque international', in Annales de l'Université d'Alger 1, 2012, p. 92.

35 C. Bontemps, 'La coutume kabyle et l'implantation des systèmes étrangers', in op. cit. p. 91. ${ }^{36}$ Ibid., p. 91 et suivante.
} 
we saw above, granted a special legal statute to the Kabyle women in the matter of divorce and inheritance.

The Algerian Supreme Court proclaimed that the Kabyle's customary law in the matter of inheritance of the women should be replaced by the Muslim law. The matter was very complicated. Indeed, during the '6os and '70s an opposition arose between the Algerian Supreme Court and the Court of Appeal of Tizi-Ouzou (Kabylia). As Bontems explains, the Supreme Court embodied the unity of Algerian law, and the Tizi-Ouzou's Court of Appel was more sensitive to the protection of the Kabyle's customary law37.

During the judgment of February $24^{\text {th }}, 1964$, the Supreme Court implicitly recognized Kabyle customs but underlined their subsidiary character. The Supreme Court granted to the populations who lived in "Kabyle's customary law territories" the choice at any time to renounce to their customs and be subjected to the Sharia (Muslim law).

The attitude of the Supreme Court toward the Kabyle's customs gets stiffed in the judgement of April 26 $6^{\text {th }}, 1967$ and May $3^{\text {rd }}, 1967$. In that abovementioned decisions, the Court proclaimed clearly that in matter of personal status, Kabyle's custom should not defeat Islamic law ${ }^{38}$ and, on April $5^{\text {th }}, 1972$ the Supreme Court overturned a decision rendered by the Court of Appeal of Tizi-Ouzou, in which the Appeal Court applied in a case of inheritance the French Decree of May $19^{\text {th }}, 1931$. The Supreme Court claimed that this decree discriminated the Kabyle's women and so the Supreme Court rejected the judgement and indirectly repealed the decree of 1931 in the name of the

37 C. BonTEMS, 'Coutume kabyle, jurisprudence et statut féminin', op. cit., p. 261. ${ }^{38}$ Ibid.,p. 53 . 
unification of Algerian law39. Two years after, this decision was repealed by the law of 1961, which maintained the French legislation.

It is interesting to compare the Algerian legislation with the Moroccan one. Indeed, despite what happened in Algeria, the Berber Dahir of May $16^{\text {th }}, 1930^{40}$ was abrogated by the Moroccan legislator. This law was adopted when Morocco was a French protectorate. This law established in Morocco special Courts for the Berber population. That Courts applied the matter of personal statutes (divorce, marriage and inheritance) the Berber customary law and not the Sharia law. So like what happened in Algeria, the Moroccan Berber populations had enjoyed a regime of exceptional legal status, consecrated by the Dahir of May $16^{\text {th }}, 1930$. This particularism was even more pronounced than in Algeria. Indeed, in the case of Algeria, the Berber populations of Kabylia were the only ones to enjoy the regime of legal exception. In the case of Morocco, this legal particularism had been applied to all Berber-speaking areas. This is the reason why in Algeria the Berber question was above all a Kabyle question.

Regarding the linguistic question, during the years 1960-1970, the Algerian legislator began the first policy of linguistic Arabisation of the Algerian legislation and of the administration. The Algerian constitutions of the years 1963, 1965, 1976 and 1989 and the National Charters of 1976 and 1986 will offer no recognition to the Berber language.

The Decree of May 22 ${ }^{\text {nd }}, 1964$ imposed the Arabisation of the administration, and Decree 64 of May $28^{\text {th }}, 1964$ proclaimed that laws and

\footnotetext{
39 Ibid., p. 263.

$4^{\circ}$ M. A. MourdJI, 'Le bilinguisme et le dualisme juridique: Une source de conflit culturel au Maroc ?' in 'Le bilinguisme juridique dans les pays du Maghreb'- Acte du colloque international', Perpignan, op. cit., p. 155.
} 
regulations should be written in Arabic. In 1962, the Berber language teaching was removed from the Faculty of Letters of Algiers. The Kabyle philologist Mouloud Mammeri required however some un-official courses of Berber language from1972 until 1968.

The main task of the policy of the Arabisation was to weaken the rule of the French language in the Algerian system, but this never happened. Indeed, the Decree number $64-147$ of May $28^{\text {th }}, 1964$, imposed a bilingual system. The law had to be drafted in Arabic and translated in French.

During the years 1960-1970, the French language did not disappear from the Algerian legal and judicial system. Indeed, the weakening of the importance of the French language in Algerian law had been gradual.

The strength of the French language was also related to the fact that during the first years of Algerian independence, France sent French magistrates to fill the lack of qualified personnel in Algeria. Indeed, in the August $28^{\text {th }}, 1962$ was signed a protocol between the two countries, which provided in article 3 that:

"As long as judges of civil status under French law participate in the functioning of the Algerian courts, the French language will be used as a working language in these jurisdictions".

and:

"Judgments are published or notified in the French language at the same time as they are published in the national language."

During the same years the first two Algerian procedural codes were adopted, the Ordinance No. 66-154 of June $8^{\text {th }}, 1966$, which ruled the civil process and the Ordinance No. 66-155 of June $8^{\text {th }}, 1966$ which ruled the criminal process. This two Codes did not contain any rule which required the use of Arabic during the civil and criminal processes. Furthermore, the 
article n. 91 of the Algerian Code of Criminal Procedure promulgated on June $8^{\text {th }}, 1966$ (Ordinance No. 66-155 of June 8, 1966) left a loophole to the regional languages as the Kabyle. This article provided that the General Attorney could be assisted by an interpreter in the case that the defendant native language was an indigenous language which differed from Arabic language. This article made a distinction between the foreign language and the "idioms" (local dialect). This article is clearly inspired by article number 332 paragraph 1 of the Code of French Criminal Procedure of 1808 (which disappeared in the French Code of Criminal Procedure of 1958).

This Code had been applied in Algeria during the French colonization, which provided that in cases where the accused, the witnesses or one of them "don't speak the same language or the same idiom, the president will appoint, on pain of nullity, an interpreter”. The French Code recognized the right to have an interpreter not only to foreigners but also to the countryside people who spoke only a local dialect. As above-mentioned, during the colonial period in the language of the French colonial legislation the French word "idiome" (idiome kabyle) was used to indicate the Kabyle language. Sometimes, the "Kabyle idiome" was opposed to the Arabic language (langue arabe) ${ }^{41}$.

The Code of Criminal Procedure of 1966, which was inspired by the French one of 1808 , gave an implicit recognition to the local languages who are predicated in Algeria. This code is still in force today in Algeria, and the article 91 above-mentioned had not be abrogated. We will come back to this point.

${ }^{41}$ For example, the decision of Supreme Court (Cour de Cassation (ch. Crim.) 21 mai 1913, in Revue algérienne, tunisienne et marocaine de législation et jurisprudence, Tome XXX year 1914, p. 19. 
That said, during the '6os and early '70s, an opposition arose to the marginalization of the Berber identity, a Berber identity movement so-called Berberism ${ }^{42}$. This movement was based in France. This movement developed around the figure of Bessaoud Arav, the founder of the Accademie berbère (Berber academy) a pan-berberist movement based in Paris ${ }^{43}$. Although this movement was pan-berberist, the majority of his members were Kabyle. The Berber movement in Algeria was, first of all, a Kabyle movement.

This Berberist political strand was opposed to the Algerian National Charter of $1976^{44}$. This Charter proclaimed the Arabisation of the Algerian law and administration. The Berberist were opposed to the marginalization of the Kabyle's language but also to the weakening of the French language. Indeed, the berberist and generally the Kabyle bourgeoisie were not hostile to the presence of the French language. A great number of militants have lived in France. The educated members of the Berber movement have studied in schools where the teaching was given in French. This was the case not only for those whom had studied during the colonial period but also for the members who studied during the post-independence period. Indeed, until the late 1970 in Kabylia there were some schools ruled by French missionaries of the order of the Pères Blancs.

\footnotetext{
$4^{2}$ From the linguistic census of 1966 it appeared that $85 \%$ of the population of the department of Tizi- Ouzou and the $40 \%$ of the p department of Setif (which, at that time, included Bejaia) declared to be native Berber speaker, see S. CHAKER, 'Le Berbere de Kabylie (Algérie'), in 'Encyclopédie berbère', XXVI, 2004, p. 4056.

43 H. RoberTs, 'The Economics of Berberism: the Material Basis of the Kabyle Question in Contemporary Algeria', in op. cit, p. 228.

44 Paradoxically, in the same year in Algiers was ratified the Universal declaration of the rights of the peoples, which proclaim in article 13 "Every people has the right to speak their language, to preserve, to develop their culture, thus contributing to the enrichment of the culture of humanity" and the article 19 proclaims that "when a people constitutes a minority within a state, it has the right to respect for its identity, traditions, language and cultural heritage. ".
} 


\subsection{B. The recognition of the Tamazight languages (1995-2016)}

The prohibition by the police authority of a conference of Mouloud Mammeri on the Kabyle poetry provoked in the spring of 1980 a revolt of the berberist students at University Campus of Tizi-Ouzou (Great-Kabylia) during the spring of 1980 . From this event arose a movement who claimed the defence of the Berber identity. The demands of this movement were initially ignored by the Algerian authority, but in the beginning of the Nineties, the government showed breasts of openness to the demands of the Berber linguistic claim. The Constitution of 1989, adopted under the pressure of the Algiers revolt of 1988, introduced in Algeria the freedom of association. So, some of Berber's cultural association were created in Kabylia. That associations were inspired by the traditional North African assemblies, well-known as djemaas.

In 1990, a Chair of Tamazight, (Berber) culture and language was created at University of Tizi-Ouzou, the same happened in 1991 in Bejaia (oriental-Kabylia) but, that said, the Tamazight languages were still excluded from administration and legislation. The Algerian government under the pressure of the rising of the Islamist political party of FIS, adopted the Law No. 91-05 of January $16^{\text {th }}$, 1991, which prohibited the use of any language other than Arabic in Courts and Administration. This law was a direct offensive against the French language and an indirect attack against the Tamazight languages 45 . For that reason, this law was severely criticized by secular parties based in Kabylia like FFS and RCD.

45 Paradoxically, as Benrabah explains, this anti-French decree is inspired by a French law. Precisely the law n. 75-1349 well known as "Loi Bas-Lauriol" adopted by the French Parliament to protect the French language from the English language. This law has imposed 
During the first half of 1990, the demands of the Tamazight culture recognition were accentuated by events such as the school boycott launched in the majority of schools in Kabylia during the years 1994-1995, in opposition to the refusal of the Algerian government to integrate Tamazight in the Algerian school system. The answer of the Algerian government was the institution by Presidential decree n. 95-147 of May $27^{\text {th }}, 1995$, of a High Commission on Amazighity and the creation of television broadcasts in the Kabyle language, and Kabyle's teaching in the schools.

The most important result of this process of openness was the Algerian constitution of 1996. This Constitution, unlike the previous one of 1989 , opened a breach with regard to the recognition of the Berber identity. The Algerian ancient chairman of Algiers Law University, Ahmed Mahiou, explained that the 1996 Constitution made Amazigh culture "the third fundamental component of Algerian identity in addition to Islam and Arab identity 46 ", but this "third component" is invoked only in the preamble and not, unlike the other two, in the device. This constitution, like the constitution of 1989 , was a rigid constitution, which provides for complex and solemn forms of revision.

During the spring of the year 2001, happened the so-called Black Spring in which other riots broke up in Kabylia. From this revolt, a new Kabyle movement was born, well known as Arch (a name taken from the ancient tribal Kabyle structure). This movement proclaimed his independence toward the political party and was constituted by a web of Kabyle Villages

the use of French language in the trade sector. M. BENRABAH, Langue et pouvoir en Algérie. Histoire d'un traumatisme linguistique, (1999), Editions Séguier, Paris, p. 126.

46 A. Mahiou, 'Note sur la constitution algérienne du 28 novembre 1996', in Annuaire de l'Afrique du Nord, 1996, p. 481. 
Committees. These villages committees proclaimed and signed an official declaration in the Kabyle village of El Kseur during the year 2002. Article o8 of this platform applied for the "(...) recognition of Tamazight as a National and Official Language". The answer of Algerian government was the recognition of the Tamazight language by the introduction of article 03-bis in the Algerian constitution, through the law n. 02-03 of April 10, 2002. This article proclaimed the Tamazight language as "also national language" but not as an official one. The article contains the following formula: "The State works to its promotion and its development in all its linguistic varieties in use on the national territory". This is a step forward from the 1996 Constitution. The Amazigh identity is no longer solely historical but now is recognized as a living identity. One of the most important aspects is represented by the fact that the Algerian legislator speaks about linguistic varieties of the Amazigh language; this is the first recognition of regional linguistic differences. It must nevertheless be emphasized that this reform was adopted in a tense climate, precisely during the Kabyle crisis of 2001 and during the revolt of the archs mentioned above. We can say that the 2002 reform of the constitution of 1996 allowed only the first part of the claim of Platform in El Kseur, as we saw above, the Tamazight was not recognized as an official language. So, all the different variants of the Tamazight languages are recognized as national languages but not as official languages. Morocco has made a different choice, the Moroccan constitution of 2011 provides in Article 05 that "(...) Amazigh is an official language of the state, as heritage common to all Moroccans without exception". We observe, however, that in the case of the Moroccan reform, unlike what happened in the Algerian counterpart, there is no reference to local Amazigh linguistic variants. 
During the years following the Constitutional reform of 2002, any significant progress has been recorded in the process of recognition of Amazigh's into the Algerian legislation, administration, and judicial system. For example, the article 9 of the Code of Civil and Administrative Procedure, amended by Law 08-09 of February $25^{\text {th }}$ 2008, provides for the obligation of the use of the classical Arabic language in the petitions and pleadings of lawyers, and also in any discussion taking place in civil and administrative proceedings. Thus, although the Code of Civil and Administrative Procedure aforementioned was promulgated after the Constitutional Review Act of 2002, this Code does not depart from Law No. 91-05 of January $16^{\text {th }} 1991$, which prohibited the use in Courts of any language other than Classical Arabic. Article 07 of this law provided that Arabic is the only language for the petitions, as well as consultations and pleadings within the Courts, court decisions and judgments.

Understandably, the documents and the acts of the lawyers are written in Arabic. So, the Kabyle lawyers like any lawyer in Algeria are fluent in Arabic for the simple reason that the Algerian Law University is scheduled in Arabic.

In Kabylia, the problem that arises is that of access to justice to the non-Arabic speaker population. Indeed, article o9 of the Procedure and Administrative Procedural Code claims that all discussions that take place in the Courts must be held in Arabic. In regions like Kabylia, a great part of the population, especially the elder one, doesn't speak and understand Arabic.

In the case of the Criminal process, the situation is not much better. As we saw, the Algerian Criminal Procedure Code allows the presence of the translator only in the specific case of the translation of the testimony. But the translators are not provided for the translation of the accused. The result is 
that the accused, who are not fluent in Arabic, are not allowed to have a translator.

Usually, the Kabyle lawyers translate the decisions of the judge to their customers, but in the Algerian legal system, in the first instance process the presence of a lawyer is not always mandatory. Indeed, the Algerian Criminal Procedural Code and also the Administrative and civil procedural codes provide for the mandatory presence of lawyers only in appeals and appeals to the Supreme Court.

Now, the Constitution of 2016 recognizes Berber language as a national and an official language. This implies theoretically that all the varieties of Berber language have now the same importance than Arabic in Algeria, but the reality is still far from what is proclaimed in the Constitution.

First, article 212 (4) of the new constitution proclaims that any constitutional review can undermine the legal status of Arabic as the national and official language. Second, the officialization of the entire set of Algerian Berber languages involves bilinguals in the administration and the legislation. The actual linguistic planning of the Kabyle or any variety of Tamazight language actually spoken in Algeria, is far from being enough developed for a bilingual legal system.

The Tamazight language, in all its variants, (just like dialectal Arabic) is the language of the customary law. Kabyle as all the other Berber dialects does not have an adequate legal vocabulary. So, a long and intensive legal language planning work is necessary. Up to now, the only initiative that was taken for filling this gap has been the edition of an Amazigh-French legal dictionary. The project has been brought forward thanks to the initiative of 
the High Commission of Amazighity. A similar one was done in 1996 in Morocco47.

Actually, in the Algerian legal system, the only foreign language that occupies a certain importance remains the French language, although this language is not recognized as a national language or official language ${ }^{48}$. Most laws, although written in Arabic, are translated and easily accessible in French. It is obvious that this is due in part to the cultural weight of the French language, and especially to the fact that Algerian law is largely inspired by French law, and to the requirements related to international trade to use a strong vehicular language such as French.

To make the article 4 of the Constitution applicable, an intensive work of Amazigh's language planning is necessary, with special attention to the Kabyle variety, for the reason that Kabylia is the only Berber region of Algeria where the linguistic right is strongly claimed by the local population. As we saw, in Algeria the Berber question is mostly a Kabyle question.

In fact, in Kabylia the Kabyle language is absent in the Courts and the Public Administration. The presence of Kabyle interpreters become necessary during the trials, especially in the criminal processes. This will allow non-Arabic speakers to understand the facts and to expose them in a language that is familiar to them. The use of classical Arabic creates problems, as we have seen, in the trials that are held in departments (Wilaya) mainly Tamazight speaking. In such departments, French and Kabyle remain the language most of the time spoken (especially in rural areas).

47 A. Adghirni, A. Afulay, F. LAhbib, 'Amawal azerfan. Lexique juridique français-amazigh. 1368 termes', Tizrigin Imperial, Rabat, 1996.

48 R. BABADJI, 'Désaroi bilingue, note sur le bilinguisme en Algérie', in Droit et Société, 1990, pp. 207-217. 
The topic of the linguistic rights of Imazighen (Berber) in Algeria as in all the Maghreb countries is part of the complex problem of national minorities in African countries, resulting from a process of decolonization. The requirement to take charge of Amazigh linguistic variants is also increased by the fact that Algeria has ratified various regional and international treaties which enshrine the cultural rights of national minorities. From the point of view of international law, the Kabyle as well as other Berber speaking minorities (as Chaouïa, Mzab, and Tuareg) fall entirely within the category of national minorities as defined by international law. Indeed, in 1977, The UN reporter Capotorti defined the national minority as:

"A group numerically inferior to the rest of the population of a State, in a non-dominant position, whose members - being nationals of the State possess ethnic, religious or linguistic characteristics differing from those of the rest of the population and show, if only implicitly, a sense of solidarity, directed towards preserving their culture, traditions, religion or language ${ }^{49}$ "

The Constitutional reform of the March $6^{\text {th }} 2016$ was received with coldness by the Kabyle. This is caused by the disappointment due to the poor results achieved with the 2002 constitutional reform. The article 4 of the new Algerian constitution certainly marks a step forward in the recognition of Amazigh languages, but a total bilingual legal system, as it's happens in Canada or Belgium, is a horizon still far away.

49 Rapport, 'Droit des minorités : Norme internationales et indications pour leur mise en œuvre', Haut-commissariat des Nation Unies, NU, New York et Genève, 2010. 


\section{CONCLUSION}

The matter of the relationships that the Algerian Law has maintained with the Berber question is a complicated question. The Berber question in Algeria is mostly a Kabyle question. The origin of this question is rooted in the colonial period.

The attitude of the Algerian legislator toward the Tamazight language, and generally the Amazigh cultural fact, can be schematized in two historical phases: a first that goes from independence (1962) to 1995 which is characterized by an attitude of total denial, and a second phase that runs from the 1996 Constitution to the present days and which is characterized by linguistic and cultural reconciliation which led to recognition of Tamazight languages as national languages in 2002, and as national and official languages in 2016. The current state of the Algerian legal system makes this reform hardly applicable. This is due to different factors such as inadequate legislation, a low level of language planning and a centralized state. Without a reform of these three elements, the officialization of Tamazight languages risks becoming a dead letter. 